\title{
Public Participation In Rural Development Playning
}

\author{
Cut Asmaul Husna ${ }^{1}$ \\ (Departement Public Administrasion, Teuku Umar University) \\ Acutbusu2@yahoo.com \\ Nellis Mardhiah ${ }^{2}$ \\ (Departement Public Administrasion, Teuku Umar University) \\ nellismardhiah@utu.ac.id
}

\begin{abstract}
The participation of community in the village consultative meetings deliberation the construction of village that it is extremely important to obtain agreement to distribute the need priority of and activities village which is going to be a material of wool or the preparation of planning documents the construction village. Method of was used in the study of the qualitative analysis to explain data offered for its shares against an informant who was chosen and foreordained destined in accordance with the technique of purposive the sampling method source of information this research data likely arrival at opportunity to discuss these matters have been analyzed using a groove the reduction data, presentation data and conclusion data.The result of this research it was discovered that the the participation of the community its shares were already built by the to be well implemented, but have not been goes on the road with a maximum. Indicators of the quality of contribution of the community should already good because in their business over consultation the community has already been give turn of thought and is a proposal of development planning village and the craving and passionate to give the community ideas related to with development planning village.
\end{abstract}

Keywords: Community, Partisipation, Development 


\section{Pendahuluan}

Pembangunan merupakan suatu proses multidimensi yang meliputi proses reorganisasi dan pembaharuan seluruh sistem serta aktivitas dalam hal ekonomi dan sosial dengan tujuan mensejahterakan kehidupan masyarakat. Indonesia merupakan negara yang luas wilayahnya dimana sebagian besar wilayah Indonesia adalah pedesaan, maka dapat dikatakan bahwa pembangunan desa memiliki peran penting dalam terwujudnya pembangunan Nasional secara lebih merata (Riyadi \& Bratakusumah. 2010, h. 10).

Pembangunan desa memiliki arti penting, karena pembangunan desa ditujukan agar penduduk bukan hanya mampu memenuhi kebutuhanya sendiri tetapi juga mampu menggali segala potensi sumber daya yang ada di desa. Oleh karena itu, dalam pembangunan desa, partisipasi atau keterlibatan masyarakat sangat dibutuhkan dalam usaha terselenggaranya pembangunan, partisipasi masyarakat didasarkan atas kemauan diri sendiri artinya masyarakat desa ikut serta dalam pembangunan atas dasar keyakinan dan kesadaran yang datang dari dalam diri mereka sendiri (Widjaja, 2010, h. 17).

Agar upaya pembangunan desa memenuhi apa yang diinginkan maka menurut Widjaja (2010, h. 18) diperlukan suatu perencanaan, penerapan perencanaan pembangunan harus bersumber pada prinsip dasar pembangunan daerah yaitu dari, oleh, dan untuk masyarakat daerah itu sendiri. Selain itu untuk mengembangkan dan melembagakan partisipasi masyarakat dalam pembangunan harus diciptakan perubahan sautu persepsi pemerintah dalam pembangunan serta untuk membangkitkan partisipasi masyarakat dalam pembangunan diperlukan sikap toleransi dari aparat pemerintah terhadap kritik yang diberikan oleh masyarakat karena kritik merupakan salah satu bentuk dari pertisipasi masyarakat.

Berkaitan dengan partisipasi masyarakat, maka dalam Undang-Undang Nomor 6 tahun 2014 tentang Desa mengamanatkan berbagai macam peran masyarakat desa dalam penyelenggaraan desa, baik dalam bidang pemerintahan, pembangunan, dan bidang lainnya. Dalam pembentukan desa misalnya, prakarsa masyarakat adalah salah satu hal yang harus dipertimbangkan dalam pembentukan desa. Masyarakat desa pun diberikan hak untuk mendapatkan informasi sekaligus mengawasi jalannya pemerintahan desa dan aspek-aspek lain di dalamnya.

Qanun Kabupaten Aceh Barat Nomor 6 tahun 2015 tentang Pemerintah Gampong menyebutkan bahwa Gampong adalah kesatuan masyarakat hukum yang merupakan organisasi pemerintahan terendah langsung berada di bawah mukim dan dipimpin oleh keuchik yang menempati wilayah tertentu, yang dipimpin keuchik yang berhak menyelenggarakan urusan rumah tangga sendiri. Kemudian berkaitan dengan partisipasi masyarakat dalam perencanaan pembangunan Gampong, di atur dalam Peraturan Bupati Aceh Barat Nomor 95 tahun 2017 tentang Pedoman Pelaksanaan Musyawarah Perencanaan Pembangunan di Tingkat Gampong, yang menyebutkan bahwa pentingnya partisipasi masyarakat dalam pelaksanaan musyawarah pembangunan Gampong dalam 
menyepakati prioritas kebutuhan dan kegiatan Gampong yang akan menjadi bahan penyusunan dokumen perencanaan pembangunan Gampong.

Keuchik Gampong di Aceh Barat menyebutkan bahwa rendahnya partisipasi masyarakat dalam perencanaan pembangunan karena kesibukan masyarakat dalam bekerja yang mayoritas pekerjaan masyarakat sebagaian besar adalah nelayan dan petani menjadi alasan utama masyarakat untuk tidak hadir dalam musyawarah renvana pembangunan.

Dari wawancara selanjutnya yang penulis lakukan terhadap Keuchik Gampong berkaitan dengan masih rendahnya partisipasi kehadiran masyarakat dalam musyawarah perencanaan pembangunan dipengaruhi oleh beberapa faktor diantaranya (a) keterbatasan pengetahuan masyarakat terhadap pemahaman pentingnya perencanaan pembangunan, dan (b) adanya sikap pesimis masyarakat terhadap proses perencanaan pembangunan karena usulan-usulan mereka tidak terakomodasi dalam proses yang lebih tinggi.

\section{Tinjauan Pustaka}

Mubyarto mendefenisikan partisipasi sebagai dana dan daya yang dapat disediakan atau dapat dihemat sebagai sumbangan, sedangkan Tjokroamidjojo dalam Ndraha (2008, h.149) mendefenisikan partisipasi sebagai kontribusi masyarakat kepada proyek-proyek pemerintah atau keterlibatan masyarakat dalam penentuan arah, strategi dan kebijaksanaan pembangunan yang dilakukan oleh pemerintah, keterlibatan masyarakat dalam memikul beban dan dalam memetik hasil atau manfaat pembangunan. Dalam hubungan ini, menggerakkan partisipasi masyarakat diartikan sebagai usaha untuk menggali, menggerakkan dan mengerahkan dana dan daya dari masyarakat dalam rangka mensukseskan program-program pemerintah.

Soetrisno (2005, h.207) mendefenisikan partisipasi sebagai kemauan rakyat untuk mendukung secara mutlak program-program pemerintah yang ditentukan dan tujuannya oleh pemerintah. Soetrisno (2005, h.208) juga menambahkan bahwa partisipasi adalah kerja sama antara rakyat dan pemerintah dalam merencanakan, melaksanakan, melestarikan dan mengembangkan hasil pembangunan.

Menurut Hoofsteede dalam Khairuddin (2003, h. 124) mengatakan bahwa partisipasi berarti ambil bagian dalam satu tahap atau lebih dari suatu proses pembangunan. Dalam pengertian ini paling tidak dapat dijumpai adanya tiga hal pokok, yaitu partisipasi merupakan keterlibatan mental emosional; partisipasi menghendaki adanya konstribusi terhadap kepentingan atau tujuan kelompok; dan partisipasi merupakan tanggungjawab terhadap kelompok.

Dari pendapat di atas dapat disimpulkan bahwa yang dimaksud partisipasi adalah peran serta warga desa baik dalam merencanakan, melaksanakan, mempertanggungjawabkan maupun dalam menerima hasil-hasil pembangunan. 
Community: Volume 4, Nomor 2, Oktober 2018

ISSN: 2477-5746 e-ISSN: 2502-0544

\section{Partispasi Masyarakat}

Partisipasi publik yang bertujuan untuk mempengaruhi pengambilan keputusan oleh pihak pemerintah yang bersifat individual atau kolektif, terorganisis secara efektif dan efisien (Samuel, 1977). Menurut Adisasmita (2013, h.38) partisipasi masyarakat dapat didefenisikan sebagai keterlibatan dan pelibatan anggota masyarakat dalam pembangunan, meliputi kegiatan dalam perencanaan dan pelaksanaan (implementasi) program pembangunan. Adisasmita juga mengatakan peningkatan partisipasi masyarakat merupakan salah satu bentuk pemberdayaan masyarakat (social empowerment) secara aktif yang berorentasi pada pencapaian hasil pembangunan yang dilakukan dalam masyarakat pedesaan.

Ada tiga alasan utama mengapa partisipasi masyarakat sangat diperlukan dalam pembangunan (Conyers, 2007, h.154):

1. Partisipasi masyarakat merupakan suatu alat guna memperoleh informasi mengenai kondisi, kebutuhan dan sikap masyarakat setempat, yang tanpa kehadirannya program pembangunan serta proyek-proyek akan gagal.

2. Masyarakat akan lebih mempercayai proyek atau program pembangunan jika merasa dilibatkan dalam proses persiapkan dan perencanaannya, karena mereka akan lebih mengetahui seluk-beluk proyek tersebut dan akan mempunyai rasa memiliki terhadap proyek tersebut.

3. Timbul anggapan bahwa merupakan suatu hak demokrasi bila masyarakat dilibatkan dalam pembangunan masyarakat mereka sendiri. Dapat dirasakan bahwa masyarakat mempunyai hak untuk memberikan saran dalam menentukan jenis pembangunan yang akan dilaksanakan di daerah mereka.

Partisipasi masyarakat dapat dianggap sebagai tolok ukur dalam menilai apakah proyek yang bersangkutan merupakan proyek pembangunan desa atau bukan. Menurut Ndraha (2008, h.103-104) ada beberapa bentuk partisipasi, sebagai berikut:

1. Partisipasi melalui kontak dengan pihak lain sebagai salah satu titik awal perubahan sosial.

2. Partisipasi dalam memperhatikan/menyerap dan memberi tanggapan terhadap informasi, baik dalam arti menerima (mentaati, memenuhi, melaksanakan), mengiakan, menerima dengan syarat, maupun dalam arti menolaknya.

4. Partisipasi dalam perencanaan pembangunan, termasuk pengambilan keputusan. Perasaan terlibat dalam perencanaan perlu ditumbuhkan sedini mungkin di dalam masyarakat.

5. Partisipasi dalam pelaksanaan operasional pembangunan.

6. Partisipasi dalam menerima, memelihara dan mengembangkan hasil pembangunan.

7. Partisipasi dalam menilai pembangunan, yaitu keterlibatan masyarakat dalam menilai sejauhmana pelaksanaan pembangunan sesuai dengan rencana dan sejauhmana hasilnya dapat memenuhi kebutuhan masyarakat. 


\section{Perencanaan Pembangunan}

Sistem perencanaan pembangunan nasional berdasarkan undang-undang Nomor 25 Tahun 2004 memberikan otonomi penuh kepada daerah untuk merumuskan lebih lanjut kebijakan perencanaan daerah. Tjokroamidjojo (2008, h.12) mendefenisikan perencanaan pembangunan sebagai suatu pengarahan penggunaan sumber-sumber pembangunan termasuk sumber-sumber ekonomi yang terbatas adanya untuk mencapai tujuan keadaan sosial ekonomi yang lebih baik secara lebih efisien dan efektif.

Perencanaan pembangunan dapat diartikan sebagai suatu proses perumusan alternatif-alternatif atau keputusan-keputusan yang didasarkan pada fakta-fakta yang akan digunakan sebagai bahan untuk melaksanakan suatu rangkaian kegiatan/aktivitas kemasyarakatan, baik yang bersifat fisik (material) maupun nonfisik (mental dan spiritual), dalam rangka mencapai tujuan yang lebih baik (Riyadi, 2005, h.7).

Perencanaan pembangunan juga merupakan upaya yang bertujuan untuk memperbaiki sumber daya publik yang tersedia untuk memperbaiki kapasitas sektor swasta dan publik dalam mencifakan nilai sumber daya swasta dan publik yang bertanggung jawab demi kepentingan pembangunan masyarakat menyeluruh (Kuncoro, 2010 h. 46).

Ciri-ciri dan tujuan perencanaan pembangunan (Tjokroamidjojo, 2008, h. 49) yaitu:

1. Mencapai perkembangan sosial ekonomi yang tetap

2. Meningkatkan pendapatan perkapita.

3. Mengadakan perubahan struktur ekonomi.

4. Perluasan kesempatan kerja.

5. Pemerataan pembangunan (distributive justice).

6. Pembinaan lembaga-lembaga ekonomi masyarakat.

7. Kemandirian pembangunan.

8. Stabilitas ekonomi.

\section{Musyawarah Rencana Pembangunan}

Undang-undang Nomor 25 Tahun 2004 dikatakan bahwa sistem perencanaan nasional adalah forum antar pelaku dalam rangka menyusun rencana pembangunan nasional dan rencana pembangunan daerah. Musrenbang dilaksanakan dimulai dari tingkat desa/kelurahan, dan diakhiri pada musrenbang tingkat Provinsi. Seperti yang dikemukakan oleh Indra Bastian (2009, h.34) Musrenbang yang harus dilalui dalam perencanaan dan penganggaran daerah adalah Musrenbang tingkat desa/kelurahan, Musrenbang tingkat kecamatan, Musrenbang forum SKPD, Muserenbang tingkat kabupaten/kota, dan Musrenbang tingkat provinsi.

Adapun Musrenbang Desa menurut Indra Bastian (2009, h.35) adalah forum rembug warga yang dilakukan untuk membicarakan masalah dan potensi desa agar teridentifikasi dengan baik untuk memberikan arah yang jelas atas tindakan yang layak 
menurut skala prioritas dan dilaksanakan dalam mengatasi masalah atau memaksimalkan potensi yang dimiliki sebagai dasar program kerja pemerintah desa melaksanakan penganggaran dan kegiatan tahunan desa.

Musrenbang desa dilaksanakan dengan maksud dilaksanakannya model perencanaan partisipatip di tingkat desa yang melibatkan semua komponen masyarakat, lembaga kemasyarakatan, swasta dan pemerintah desa/ lembaga pemerintah lainnya yang ada di desa. Sedangkan tujuan yang hendak dicapai dengan dilaksanakannya musrenbang desa adalah:

1. Menyepakati prioritas kebutuhan dan masalah yang sangat mendesak untuk direalisasikan dalam bentuk program maupun kegiatan pada tahun perencanaan/ tahun yang akan datang.

2. Menyepakati tim delegasi desa yang akan memaparkan masalah yang menjadi kewenangan daerah yang berada di wilayah desa pada forum musrenbang kecamatan

Dalam menentukan kesepakatan prioritas kebutuhan dihasilkan tiga kesepakatan yang akan menjadi prioritas yaitu :

1. Menyepakati prioritas kegiatan yang akan dilaksanakan oleh desa yang akan dibiayai dari dana swadaya masyarakat dan atau dari pendapatan asli desa (PAD). Kegiatan yang mendesak untuk dilaksanakan dan sangat dibutuhkan oleh masyarakat banyak, namun kegiatan ini tidak dapat dibiayai dari dana ADD maupun Dana Desa, harus dimasukan sebagai prioritas kegiatan desa yang akan dilaksanakan sendiri oleh desa melalui swadaya masyarakat. Contoh kegiatan pembangunan mesjid/mushalla, penataan tempat pemakaman, pembangunan gapura desa dan lain-lain.

2. Menyepakati prioritas kegiatan yang akan dilaksanakan oleh desa yang akan dibiayai dari Alokasi Dana Desa (ADD), Dana Desa (DD).

3. Menyepakati prioritas masalah daerah yang ada di desa yang menjadi kewenangan pemerintah daerah maupun pusat dan akan pada musrenbang kecamatan untuk diusulkan menjadi kegiatan yang dibiayai APBD pemerintah daerah kabupaten/kota maupun provinsi. Contoh pembangunan jalan desa yang berstatus jalan kabupaten atau provinsi, pembangunan saluran irigasi tersier maupun sekunder yang menjadi kewenangan pemerintah daerah.

\section{Pembangunan Desa}

Pencapaian keberhasilan yang maksimal, maka suatu kegiatan sangat dipengaruhi oleh ketetapan pengorganisasian, sistem kerja yang dijalankan dan unsurunsur pendukungnya, yaitu mutu personilnya serta sarana yang diperlukan. Dalam keadaan demikian, maka akan dapat dicapai suatu penyelenggaraan pemerintahan dan pembangunan yang berdayaguna dan berhasilguna. Seiring dengan hal tersebut, maka dalam penyelenggaraan pembangunan desa diperlukan pula pengorganisasian yang 
dapat menggerakkan masyarakat untuk berpartisipasi dalam pembangunan desa, serta melaksanakan administrasi pemerintahan desa yang semakin rasional, tidak didasarkan pada tuntutan emosional yang sukar dipertanggungjawabkan pelaksanaannya.

Undang-undang Nomor 6 Tahun 2014 tentang desa menjelaskan bahwa perencanan partisipasi masyarakat merupakan sasaran utama dalam perencanaan pembangunan desa dalam proses tahapan kegiatan yang diselenggarakan oleh pemerintah desa dengan elibatkan badan permusyawaratan desa dan unsur masyarakat secara partisipatif guna pemanfaatan dan pengalokasian sumber dana desa dalam rangka mencapai tujuan pembangunan desa.

Menurut Marbun (2012, h.113) bahwa pembangunan desa adalah seluruh kegiatan yang berlangsung di pedesaan dan meliputi seluruh aspek kehidupan masyarakat, dilaksanakan secara terpadu dengan mengembangkan swadaya gotongroyong masyarakat. Pembangunan desa diarahkan untuk memanfaatkan secara optimal potensi sumber daya alam, dan mengembangkan sumber daya manusianya dengan meningkatkan kualitas hidup, meningkatkan keterampilan, meningkatkan prakarsa, dengan mendapatkan bimbingan dan bantuan dari aparatur pemerintah, sesuai dengan bidang tugasnya masing-masing.

Menurut Adisasmita (2013, h.59) pembangunan perdesaan itu mempunyai ruang lingkup yang sangat luas tetapi dapat dikelompokkan sebagai berikut:

1. Pembangunan sarana dan prasaran perdesaan meliputi pengairan, jaringan jalan dan lingkup permukiman.

2. Pemberdayaan masyarakat.

3. pengelolaan sumber daya alam (SDA) dan peningkatan sumber daya manusia (SDM).

4. Penciptaan lapangan kerja, kesempatan berusaha, peningkatan pendapatan khususnya terhadap daerah perdesaan yang miskin.

5. Peningkatan keterkaitan antar daerah perdesaan dan antara daerah perdesaan dengan daerah perkotaan.

Dengan demikian, partisipasi masyarakat secara langsung dalam tiap tahap proses pembangunan adalah merupakan ciri utama pembangunan desa yang ideal, sebab dalam proses pembangunan partisipasi masyarakat berfungsi sebagai masukan dan keluaran, yang mana proses partisipasi dapat diklasifikasikan menjadi 6 tahap yaitu mulai dari penerimaan informasi, pemberian tanggapan terhadap informasi, perencanaan, pelaksanaan, penelitian, dan penerimaan kembali hasil.

Pembangunan sebagai input atau masukan pembangunan disini diharapkan dengan adanya partisipasi masyarakat bisa menumbuhkan kemampuan masyarakat untuk berkembang secara mandiri sedangkan sebagai output atau keluaran partisipasi merupakan proses keluaran stimulasi atau motivasi melalui berbagai upaya. Untuk meningkatkan partisipasi masyarakat dalam pembangunan maka dapat digunakan kerangka konsep sebagai berikut : 
1. Partisipasi perlu dikembangkan dengan pola prosedural yaitu masyarakat atau kelompok sasaran diharapkan berperan serta aktif pada berbagai tahap dalam proses aktifitas pembangunan ekonomi.

2. Upaya meningkatkan kesadaran, kemauan, dan kemampuan golongan miskin untuk berpartisipasi. Hal ini dimaksudkan agar mereka berpartisipasi dan bias menolong perekonomian diri sendiri.

3. Program-program pembangunan sosial ekonomi yang hendak dikembangkan perlu diperhatikan.

4. Keterlibatan agen pembaharu dari luar komunitas hanya sejauh memberikan dorongan dan membantu memudahkan atau partisipasi warga masyarakat dan bukan berperan sebagai pelaku utama.

5. Partisipasi perlu dilaksanakan melalui lembaga-lembaga yang sudah dikenal atau kelompok yang dibentuk dari prakarsa warga masyarakat.

\section{Metode Penelitian}

pendekatan kualitatif dengan metode penelitian deskriptif. Peneliti menggunakan pendekatan kualitatif dikarenakan peneliti dalam melakukan usulan penelitian secara langsung di lapangan. Menurut Bogdan dan Taylor (1975) dalam Moleong (2009, h.4) mendefinisikan metodelogi kualitatif sebagai prosedur penelitian yang menghasilkan data deskriptif berupa kata-kata tertulis atau lisan dari orang-orang dan perilaku yang dapat diamati. Selanjutnya menurut Denzim dan Lincoln (1987) dalam Moleong (2009, h.5), penelitian kualitatif deskriptif adalah metode penelitian yang menggunakan latar belakang alamiah. Teknik yang digunakan dalam pengumpulan data penelitian ini adalah wawancara. Pendapat Bungin (2008, h.108) yang menyatakan bahwa karakter utama dari wawancara ini adalah dilakukan secara bertahap dan pewawancara tidak harus terlibat dalam kehidupan sosial informan. Kehadiran wawancara sebagai peneliti yang sedang mempelajari objek penelitian yang dapat dilakukan secara tersembunyi dan terbuka. Penggunaan pedoman wawancara dalam penelitian adalah teknik pengumpulan data dari informan sebagai sumber data primer dengan cara mengajukan daftar materi wawancara serta dokumentasi, Dokumentasi adalah pencatatan berbagai arsip dan dokumentasi yang ada hubungannya dengan penelitian. Dokumentasi bertujuan untuk mempelajari dan menelusuri data yang bersumber pada informasi yang bersumber dari dokumen; buku, jurnal, surat kabar, majalah, laporan kegiatan, notulen rapat, daftar nilai, kartu hasil studi, transkrip, prasasti dan yang sejenisnya.

\section{Hasil dan Pembahasan}

Musyawarah perencanaan pembangunan gampong adalah forum musyawarah tahunan para pemangku kepentingan (stakeholder)di gampong untuk menyepakati rencana kegiatan untuk tahun anggaran berikutnya. Musrenbang pembangunan gampong untuk menyusun rencana kegiatan tahunan dengan mengacu/memperhatikan 
pada rencana pembangunan jangka menengah Gampong (RPJMG) yang telah disusun untuk 5 tahun kedepan.

Musrenbang adalah forum publik perencanaan (program) yang diselenggarakan oleh lembaga publik yaitu pemerintah kelurahan bekerjasama dengan warga dan para pemangku kepentingan. Penyelenggaraan musrenbang merupakan salah satu tugas pemerintah kelurahan untuk menyelenggarakan urusan pemerintahan,pembangunan dan kemasyarakatan. Pembangunan tidak akan bergerak maju apabila salah satu saja dari tiga komponen tatapemerintahan (pemerintah, masyarakat, swasta) tidak berperan atau berfungsi. Karena itu, musrenbang juga merupakan forum pendidikan warga agar menjadi bagian aktif dari tatapemerintahan dan pembangunan.

Konsep musyawarah menunjukkan bahwa forum musrenbang bersifat partisipatif dan dialogis. Musyawarah merupakan istilah yang sebenarnya sudah jelas berarti merupakan forum untuk merembukkan sesuatu dan berakhir pada pengambilan kesepakatan atau pengambilan keputusan bersama. Bukan seminar atau sosialisasi informasi. Proses musrenbang jangan sampai disusun sebagai suatu acara seremonial yang separuh atau sebagian besar dari waktunya diisi dengan sambutan-sambutan atau pidato-pidato, karena inti dari musrenbang adalah partisipasi aktif warga.

Berkaitan dengan Musyawarah Perencanaan Pembangunan (Musrenbang) dalam Peraturan Bupati Aceh Barat Nomor 95 tahun 2017 tentang Pedoman Pelaksanaan Musyawarah Perencanaan Pembangunan di Tingkat Gampong, pada pasal 1 ayat (16) disebutkan bahwa Musyawarah perencanaan pembangunan gampong yang selanjutnya disingkat dengan Musrenbang Gampong adalah musyawarah rencana pembangunan yang dilaksanakan di gampong guna menjaring aspirasi dari masyarakat termasuk dari kaum perempuan, anak dan disabilitas.

Peraturan Bupati Nomor 95 tahun 2017 tentang Pedoman Pelaksanaan Musyawarah Perencanaan Pembangunan di Tingkat Gampong menyebutkan pada pasal 3 bahwa "maksud dari pelaksanaan musrenbang Gampong adalah sebagai pedoman bagi pemerintah gampong dan masyarakat dalam rangka mewujudkan pembangunan yang berpartisipatif dan aspiratif" Jadi mengacu pada ketentuan maksud dari partisipasi adalah partisipasi masyarakat dalam suatu proses pembangunan yang direncakan dalam musrenbang, karena tujuan dari pelaksanaan musrenbang adalah membahas dan menyepakati isu dan permasalahan strategis dalam gampong, kemudian menyepakati prioritas kebutuhan dan kegiatan gampong, yang kesemua itu harus melibatkan unsur masyarakat didalamnya terutama masyarakat miskin, perempuan anak dan disablitias.

Dari wawancara yang penulis lakukan adalah semua aparatur Gampong unsur partisipan dari masyarakat yang hadir adalah ulee jurong, tokoh agama, petani, perempuan, PKK, nelayan, tenaga pengajar, pelaku usaha (wiraswasta), dan kader posyandu dan kader pemberdayaan dan masyarakat. 
Demikian halnya dalam rangka perwujudan partisipasi publik dalam perencanaan pembangunan desa tidak dapat diwujudkan pembangunan yang komprehensif adalah sebagai berikut:

a. Sikap acuh dan acuh bagi tidak tertarik dan rendahnya pemahaman masyarakat dalam masalah pembangunan dan kesejahtaraan masyarakat;

b. Upaya dan kenyakinan masyarakat dalam mepepengaruhi kebijakan pemerintah dalam pelaksanaan hasil pembangunan sesuai dengan harapan tidak berhasil;

c. Tindakan apatis bagi masyarakat dalam mengartikulasikan perencanaan dan pembangunan desa secara keberlanjutan.

\section{Kesimpulan}

Perencanaan Partisipasi masyarakat dalam rencana pembangunan masih sangat minimal. Masyarakat yang hadir dalam musrenbang telah berpartisipasi aktif yaitu berkontribusi memberikan saran dan usulan-usulan tambahan pembangunan gampong. Kendala masih rendahnya partisipasi masyarakat dalam musrenbang Gampong Pasi Mesjid adalah kurangnya pengetahuan masyarakat tentang pentingnya partisipasi masyarakat untuk hadir dalam kegiatan musrenbang gampong. Selain itu dari hasil penelitian ini juga disebutkan bahwasannya sebagaian dari masyarakat memiliki sikap yang pesimis, dengan sebab masyarakat menganggap bahwa pembangunan gampong merupakan urusan Keuchik beserta apartur gampong.

Perencanaan pembangunan pedesaaan sangat ketergantungan dengan aktivitas masyarakat, untuk itu, keterlibatan masyarakat sebagai proses perubahan sosial dalam pembangunan ke arah yang lebih baik dan dilaksanakan oleh semua komponen masyarakat desa dalam rangka meningkatkan kesejahteraan dan taraf hidup masyarakat. Maka Musyawarah Perencanaan Pembangunan Desa yang selanjutnya disebut Musrenbangdes adalah forum perencanaan pembangunan di tingkat desa yang diselenggarakan oleh pemerintah desa dan melibatkan partisipasi masyarakat dengan semangat musyawarah untuk mufakat.

\section{Daftar Pusataka}

Abe, Alexander. 2005. Perencanaan Daerah Pertisipatif. Yogyakarta: Pembaharuan

Bungin, Burhan. 2008. Penelitian Kualitatif. PT. RajaGrafindo Jakarta: Persada.

Kuncoro, Mudrajad. 2010. Otonomi Dan Pembangunan Daerah: Reformasi, Perencanaan, Strategi dan Peluang. Jakarta: Erlangga

Laily. 2015. Khoiruddin. 2010. Partisipasi Masyarakat Pedesaan. Jakarta: Bumi Aksara.

Moleong, Lexy J. 2009. Metode Penelitian Kualitatif. Bandung: Remaja Rosdakarya 
Nurcholis, Hanif. 2005. Teori dan Praktik Pemerintahan dan Otonomi Daerah. Jakarta: Grasindo

Riyadi dan Bratakusumah. 2010. Perencanaan Pembangunan Daerah. Jakarta: PT Gramedia Pustaka Utama

Soetrisno, Lukman. 2005. Menuju Masyarakat Partisipatif. Yogyakarta: Kanisius

Sugiyono. 2009. Metode Penelitian Administrasi. Bandung: Alfabeta

Tjokromidjojo, Bintoro. 2008. Perencanaan Pembangunan. Jakarta: CV Haji Masagung

Wrihatnolo, R. 2006. Manajemen pembangunan Indonesia: Sebuah Pengantar dan Panduan. Jakarta: Elex Media Komputindo

Wirawan, R. dkk. 2015. Partisipasi Masyarakat Dalam Perencanaan Pembangunan Daerah . Jurnal Ilmu Sosial dan Ilmu Politik ISSN. 2442-6962 Vol. 4, No. 2 Program Magister Ilmu Administrasi Publik, Universitas Brawijaya. 